\title{
ANALISIS PREFERENSI PELANGGAN PT. PLN (PERSERO) DALAM MENENTUKAN ATRIBUT REKENING LISTRIK PRABAYAR DI KOTA AMBON DENGAN MENGGUNAKAN METODE ANALISIS KONJOIN
}

\author{
${ }^{1}$ M. Yahya Matdoan, ${ }^{2}$ Elvinus R. Persulessy, ${ }^{3}$ F. Kondo Lembang \\ 1,2,3 Jurusan Matematika FMIPA, Universitas Pattimura \\ Jl. Ir. M. Putuhena, Kampus Unpatti, Poka-Ambon, Indonesia \\ e-mail: matdoanyahya354@gmail.com
}

\begin{abstract}
Abstrak
Analisis konjoin merupakan salah satu teknik analisis multivariat yang digunakan untuk mengetahui preferensi konsumen terhadap suatu produk, baik berupa barang atau jasa dengan cara mengkombinasikan jumlah nilai dari masing - masing atribut yang terpisah. Oleh karena itu, penggunaan analisis konjoin sangat membantu penelitian dalam pemasaran terutama penting tidaknya suatu atribut beserta taraf dalam suatu produksi atau jasa. Hasil pengolahan analisis konjoin pada penelitian ini mendapatkan informasi bahwa faktor utama kepuasan pelanggan di Kota Ambon terhadap produk listrik prabayar yaitu konsumen lebih menyukai produk listrik prabayar yang memiliki garansi kerusakan, tempat pembelian voucher listrik di kios terdekat, tampilan warna rekening produk berwarna putih dan media pengaduan pelanggan melalui telepon.
\end{abstract}

Kata Kunci : analisis konjoin, atribut, preferensi

\section{ANALYSIS CUSTOMER PREFERENCES OF PT PLN (PERSERO) IN DETERMINING ELECTRIC ACCOUNT ACHIEVEMENT ATTRACTION IN AMBON CITY USING CONJOINT ANALYSIS}

\begin{abstract}
Conjoint analysis is one multivariate analysis technique used to know consumer preference to a product, either in the form of goods or service by way of combine amount of value from each separate attribute. Therefore, the use of conjoint analysis is very helpful in marketing research, especially the importance of an attribute and the level in a production or service. The result of the analysis of konjoin analysis in this research get information that the main factor of consumer satisfaction in Ambon city to prepaid electricity product is consumer prefer pre-paid electricity product which has damage warranty, place of purchase of electric voucher at kiosk nearby, white product account color display and complaint media customers by phone.
\end{abstract}

Keywords: attributes, conjoint analysis, preferences

\section{Pendahuluan}

Di era Globalisasi perkembangan Dunia bisnis, teknologi dan investasi semakin pesat. Setiap perusahan menghadapi persaingan yang ketat, sehingga peran perusahan dalam hal inovasi produk penting dan sangat menentukan. Kepuasan pelanggan adalah perasaan senang atau kecewa seseorang yang muncul setelah membandingkan antara produk yang dipikirkan terhadap kinerja yang diharapkan [1]. Setiap negara memiliki tujuan untuk mensejahterakan masyarakatnya. Hal ini dikarenakan kesejahteraan merupakan tolak ukur pembangunan nasional. Oleh karena itu, pemerintah dituntut untuk memberikan pelayanan kepada masyarakat dalam rangka mewujudkan kesejahteraan. Salah satu perusahaan yang bergerak dalam bidang pelayanan kepada masyarakat adalah PT. Perusahan Listrik Negara (PLN). PT PLN (Persero) merupakan Badan Usaha Milik Negara (BUMN) yang bergerak dalam bidang kelistrikan di Indonesia. Pada awalnya PT. PLN (Persero) melayani kelistrikan pelanggan dengan cara program listrik pascabayar. Namun dalam pelaksanaannya, listrik pascabayar menimbulkan beberapa masalah diantaranya tagihan tidak menentu, salah 
baca meteran, tunggakan rekening rumah, kos atau kontrakan, dan lain-lain. Oleh karena itu, PT. PLN (Persero) memberikan inovasi baru dalam pelayanan publik berupa listrik prabayar atau biasa disebut listrik pintar [2].

Sejak diluncurkan pada Januari 2008, listrik prabayar menjadi salah satu pilihan masyarakat dalam memudahkan pemakaian listrik. Rekening Listrik prabayar merupakan cara pembelian listrik dimana pelanggan membayar terlebih dahulu baru kemudian menikmati aliran listrik. Keunggulan dari listrik prabayar adalah pelanggan lebih bijak mengelola pemakaian listrik sendiri, tidak akan ada lagi tunggakan yang mengakibatkan aliran listrik dicabut dan petugas PT. PLN (Persero) tidak lagi ke lapangan untuk mengecek meteran rekening listrik Pelanggan. Kebutuhan akan jasa listrik di Kota Ambon dari tahun ketahun menunjukan adanya peningkatan. Namun melihat kondisi saat ini jumlah pengguna rekening listrik prabayar masih sedikit, hal ini disebabkan karena sistem yang masih begitu belum baik dan aplikasi rekening listrik prabayar yang masih minim juga merupakan masalah bagi konsumen. Oleh karena itu, tujuan dipasarkanya rekening listrik prabayar dapat dikatakan belum tercapai. Melihat kondisi ini, pihak PT. PLN (Persero) harus menawarkan produk yang sesuai dengan kebutuhan dan keinginan pelanggan, dengan kata lain, harus memahami atribut maupun fitur apa saja yang diharapkan konsumen di dalam produk tersebut agar dapat meningkatkan kepuasan pelanggan.

Merujuk informasi diatas, penelitian ini dilakukan untuk mengetahui atribut rekening listrik prabayar yang diinginkan sebagian besar responden. Analisis konjoin adalah salah satu teknik analisis multivariat yang mampu mendesain suatu bentuk produk beserta atribut-atributnya yang diinginkan konsumen, serta analisis ini juga dapat digunakan untuk mengetahui bagaimana persepsi konsumen terhadap produk rekening listrik prabayar. Analisis konjoin merupakan teknik Analisis Peubah Ganda (APG) yang unik dibandingkan dengan teknik Analisis Peubah Ganda (APG) lainnya, karena peneliti terlebih dahulu harus membentuk produk atau jasa yaitu dengan cara mengkombinasikan level-level pada setiap peubah dari seluruh kemungkinan kombinasi yang terbentuk dan analisis ini dapat menduga pada taraf individual [3].

\section{Tinjauan Pustaka}

\subsection{Sejarah Analisis Konjoin}

Analisis Konjoin berawal sekitar tahun 1960-an, dengan dipublikasikan sebuah artikel oleh Luce (psikolog) dan Tukey (statistik) di journal of mathematical psychology pada tahun 1964. Artikel tersebut membahas tentang pengukuran analisis konjoin dengan menggunakan skala interval. Sejak pertengahan 1970-an [4], analisis konjoin telah menarik banyak perhatian peneliti sebagai salah satu metode yang dapat menggambarkan secara nyata keputusan konsumen sebagai trade off di antara produk atau jasa dengan multi atribut. Kemudian di tahun 1980-an analisis konjoin banyak di publikasikan secara luas di bidang industri. Selama era 1990-an, penggunaan analisis konjoin meluas ke berbagai bidang ilmu pengetahuan. Seiring dengan perkembangan zaman analisis konjoin dapat di kembangkan secara luas dalam menciptakan produk baru yang mengarah pada pemakaianya di berbagai bidang, seperti segmentasi pasar, pemasaran, penetapan harga, dan periklanan [5].

\subsection{Analisis Konjoin}

Analisis Konjoin (Conjoint Analysis) merupakan suatu metode analisis dalam analisis multivariat. Metode ini digunakan untuk menentukan tingkat kepentinga relatif berdasarkan presepsi pelanggan yang dibawa oleh suatu produk tertentu dan nilai kegunaan yang muncul dari atribut-atribut produk terkait [6]. Secara umum model analisis konjoin dapat diformulasikan sebagai berikut :

$$
\begin{array}{cl}
Y_{1} & =X_{1}+X_{2+\ldots}+X_{n} \\
\text { Metrik/Non Metrik } & \text { Non Metrik }
\end{array}
$$

Keterangan :

Variabel independen ( $X_{1}$ dan seterusnya) : Faktor, data yang berupa data non metrik.

Variabel dependen $\left(Y_{1}\right)$ : Pendapat keseluruhan (overall preference) dari seseorang responden terhadap sekian faktor dan level pada sebuah produk dan juga mencakup tingkat kepentingan faktor seseorang responden terhadap atribut-atribut produk terkait.

Model dasar analisis konjoin secara matematis sebagai berikut : 
dimana :

$$
\mu(x)=\sum_{i=1}^{m} \sum_{j=1}^{k} a_{i j} x_{i j}
$$

$\mu(x)$ : Seluruh utility dari suatu alternatif

$a_{i j} \quad$ : Sumbangan the part-worth atau utility taraf ke- $j$ atribut ke- $i$

$k_{i} \quad$ : Banyaknya level atribut ke- $i$

$m$ : Banyak atribut

$X_{i j}:$ Dummy variable atribut ke- $i$ taraf ke- $j$ (bernilai 1) jika level ke-j dari atribut ke- $i$ terjadi, 0 jika tidak terjadi.

Utilities level adalah nilai pentingnya suatu level terhadap level lainya pada suatu atribut $\left(I_{i}\right)$ dinyatakan dalam kisaran parth worth yaitu selisih antara nilai part-worth terbesar dan terkecil. Sedangkan faktor importance $\left(W_{i}\right)$ adalah nilai yang menunjukan tingkat kepentingan relatif suatu atribut dibandingkan dengan atribut lainya, di formulasikan [6] :

$$
w_{i}=\frac{I_{i}}{\sum_{i=1}^{m} I_{i}} \times 100
$$

Keterangan :

$w_{i} \quad$ : Pentingnya atribut (factor importance) ke- $i$

$I_{i} \quad$ : Range nilai kepentingan untuk tiap atribut

Range nilai kepentingan relatif tiap atribut dapat dicari dengan rumus sebagai berikut [6] :

$$
I_{i}=\left[\max \left(a_{i j}\right)-\min \left(a_{i j}\right)\right]
$$

Dalam evaluasi model, hasil analisis konjoin dinilai untuk akurasi baik individu maupun agregat. Tujuan keduanya adalah untuk memastikan seberapa konsisten model untuk memprediksi preferensi yang diberikan responden. Untuk memeriksa kecocokan model keseluruhan dapat digunakan nilai korelasinya, Semakin tinggi korelasinya semakin cocok atau semakin baik modelnya.

\subsection{Uji Ketepatan Prediksi}

Untuk menguji ketepatan prediksi dalam analisis konjoin dilakukan dengan menggunkan korelasi Pearson's $R$ dan Tau Kendal. Pedoman untuk uji signifikansi adalah :

$H_{0}$ : Tidak ada hubungan yang kuat antara variabel estimasi dengan observasi.

$H_{1}$ : Ada hubungan yang kuat antara variabel estimasi dengan observasi.

\subsection{Aturan Keputusan}

Jika probabilitas (significance) $>0,05$, maka $H_{0}$ diterima

Jika probabilitas (significance) $<0,05$, maka $H_{0}$ ditolak

\subsection{Uji Validitas dan Uji Reliabilitas}

\subsubsection{Uji Validitas}

Uji validitas digunakan untuk menunjukan sejauh mana suatu alat ukur (kuesioner) yang digunakan untuk mengukur informasi yang diperlukan. Uji ini dilakukan dengan mengukur korelasi antara variabel/item dengan skor total variabel. Uji validitas ini menggunakan teknik korelasi product momen model pearson's dengan rumus sebagai berikut [7]:

$$
r_{x y}=\frac{n \sum x y-\sum x \sum y}{\sqrt{\left\{\left(n \sum x^{2}\right)-\left(\sum x\right)^{2}\right\}\left\{\left(n \sum y^{2}\right)-\left(\sum y\right)^{2}\right\}}}
$$

Keterangan : 


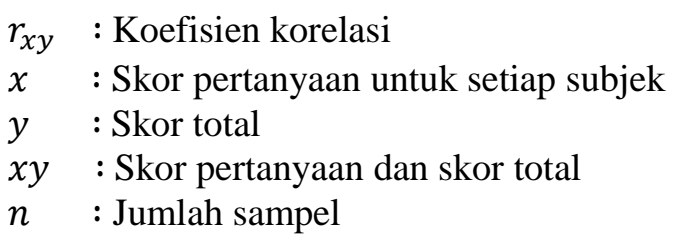

Menurut [8], bilamana koefisien korelasi antara skor suatu indikator dengan skor total keseluruhan indikator positif dan lebih besar $0,3\left(r_{x y} \geq 0,3\right)$ maka instrumen tersebut dianggap valid. atau apabila $r$ hitung masingmasing pertanyaan (dilihat pada ouput data) lebih besar dari $r$ tabel yang berarti pertanyaan valid, dan jika $r$ hitung lebih kecil dari $r$ tabel yang berarti pertanyaan tidak valid.

\subsubsection{Uji Reliabilitas}

Uji Reliabilitas merupakan indeks yang menunjukan sejauh mana suatu alat pengukuran dapat dipercaya atau dapat diandalkan. Dalam penelitian ini uji reliabilitas dilakukan dengan melihat koefisien $\alpha$ cronbach dengan rumus sebagai berikut [7] :

$$
\alpha=\left(\frac{k}{k-1}\right)\left(\frac{1-\sum \sigma_{i}^{2}}{\sigma_{i}^{2}}\right)
$$

Keterangan :

$$
\begin{array}{cl}
\alpha & : \text { Nilai alpha cronbach } \\
k & : \text { Banyaknya butir pertanyaan } \\
\sum \sigma_{i}^{2} & : \text { Jumlah varian butir } \\
\sigma_{i}^{2} & : \text { Varian total }
\end{array}
$$

\section{Metodologi Penelitian}

Data yang digunakan dalam penelitian ini adalah data primer yang diperoleh dari pengguna listrik prabayar di Kota Ambon. Pengambilan data dilakukan dengan menggunakan teknik probability sampling. [8] Skala kuesioner yang digunakan adalah skala likert, dengan penentuan sampel sebagai berikut :

\begin{tabular}{|c|c|c|c|}
\hline Tabel 1. Data Pengguna Listrik Prabayar di Kota Ambon \\
\hline No. & Nama & Jumlah Pelanggan & Presentase \\
\hline 1. & PT PLN Rayon Kota & 8.532 & $45 \%$ \\
\hline 2. & PT PLN Rayon Baguala & 7.464 & $40 \%$ \\
\hline 3. & PT PLN Rayon Nusaniwe & 2.817 & $15 \%$ \\
\hline \multicolumn{2}{|c|}{ Total } & 18.813 & $100 \%$ \\
\hline
\end{tabular}

Sumber : PT. PLN (Persero) Cabang Ambon

Berdasarkan Tabel 1, dapat dilihat bahwa pelanggan listrik prabayar di kota Ambon sebanyak 18.813 pelanggan. Sampel dalam penelitian ini adalah sebagian dari populasi atau sebagian dari pelanggan listrik prabayar yang ada di Kota Ambon. Pengambilan banyaknya jumlah sampel menggunakan metode slovin.

$$
\begin{aligned}
n & =\frac{N}{1+N e^{2}} \\
\boldsymbol{n} & =\frac{\mathbf{1 8 . 8 1 3}}{\mathbf{1 + \mathbf { 1 8 . 8 1 3 } ( \mathbf { 0 } , \mathbf { 1 } ) ^ { 2 }}} \\
& =\frac{18.813}{1+18.813(0,01)} \\
& =\frac{18.813}{189,13} \\
& =99,47
\end{aligned}
$$

Berdasarkan perhitungan, maka diperoleh sampel sebanyak 99,47 dibulatkan menjadi 100. Jadi, sampel dalam penilitian ini adalah 100 responden $(n=100)$. 


\section{Hasil Dan Pembahasan}

\subsection{Penyusunan Kuesioner}

Untuk mengetahui preferensi konsumen terhadap atribut rekening listrik prabayar, disusunlah kuesioner yang kemudian disebarkan kepada responden. Berikut ini adalah hal-hal yang dihasilkan dari penyebaran kuesioner prefernsi pelanggan :

1. Kombinasi atribut dan level dari produk listrik prabayar yang optimal.

2. Tingkat utilitas level-level dari produk listrik prabayar.

3. Tingkat kepentingan atribut-atribut listrik prabayar.

\subsection{Penentuan Atribut Produk}

Penetuan atribut produk listrik prabayar dalam kuesioner ini berdasarkan pada hasil studi literatur dan diskusi dengan pengguna listrik prabayar.

\subsection{Penyusunan Level Pada Atribut}

Berdasarkan hasil dari interpretasi kebutuhan pelanggan listrik prabayar, diperoleh empat atribut yang dinilai penting dalam produk listrik prabayar. Adapun keempat atribut dan taraf-tarafnya dapat dilihat pada Tabel 2.

Tabel 2. Atribut dan Level Listrik Prabayar

\begin{tabular}{|c|c|l|}
\hline Atribut & Taraf & \multicolumn{1}{|c|}{ Level } \\
\hline \multirow{4}{*}{ Warna } & 1 & Putih \\
\cline { 3 - 3 } & 2 & Kuning \\
\cline { 3 - 3 } & 3 & Biru \\
\hline \multirow{2}{*}{ Tempat } & 1 & Loket PLN \\
\cline { 3 - 3 } & 2 & Bank \\
\cline { 3 - 3 } & 3 & Kios \\
\hline \multirow{2}{*}{ Media Pengaduan } & 1 & SMS \\
\cline { 3 - 3 } & 2 & Telepon \\
\hline \multirow{2}{*}{ Jaminan Garansi } & 1 & Ya \\
\cline { 3 - 3 } & 2 & Tidak \\
\hline
\end{tabular}

\subsection{Mendesain Stimuli}

Stimuli merupakan kombinasi antara atribut atau faktor (Warna, Tempat, Media dan Garansi) dan sepuluh level atau sub atribut (tiga untuk tampilan warna rekening listrik prabayar, tiga untuk tempat pembelian voucher listrik, dua untuk media pengaduan pelanggan dan dua untuk garansi listrik prabayar), maka kemungkinan kombinasi yang diperoleh adalah

$$
3 \times 3 \times 2 \times 2=36
$$

Dari kombinasi diatas, hal ini berarti secara teoritis responden harus menilai 36 kemungkinan kombinasi produk. Kombinasi atribut yang sangat banyak bisa melelahkan responden dan membuat responden tidak fokus memberikan jawaban, apalagi faktor dan level yang diteliti kompleks dan saling terkait. Untuk itu, prosedur stimuli pada analisis konjoin digunakan untuk membantu menciptakan kombinasi stimuli dari 36 kemungkinan tersebut. Sehingga tidak perlu menganalisis semua kombinasi lebih lanjut. Desain eksperimen dibuat berdasarkan syintax SPSS 22. Berikut adalah penulisan syntax. 


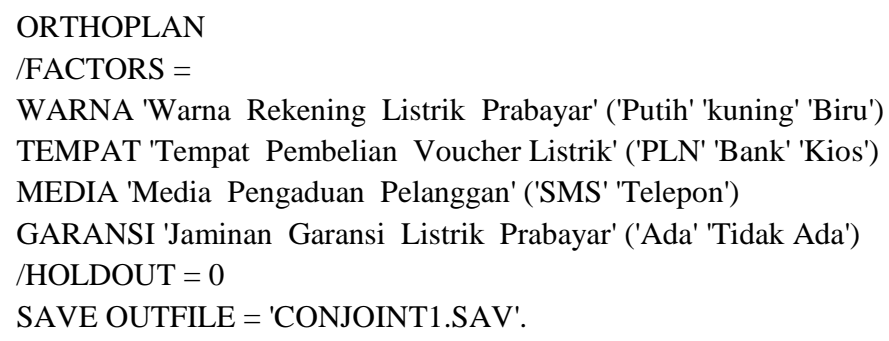

Gambar 1. Syntax pembuatan stimuli dengan program SPSS 22.

Hasil syntax stimuli SPSS pada Gambar 1 dapat dilihat pada Tabel 3.

Tabel 3. Hasil Stimuli SPSS

\begin{tabular}{|c|c|c|c|c|c|}
\hline Warna & Tempat & Media & Garansi & Status & Card \\
\hline 3 & 2 & 1 & 1 & 0 & 1 \\
\hline 3 & 3 & 1 & 2 & 0 & 2 \\
\hline 2 & 1 & 1 & 2 & 0 & 3 \\
\hline 2 & 3 & 2 & 1 & 0 & 4 \\
\hline 2 & 2 & 1 & 1 & 0 & 5 \\
\hline 1 & 3 & 1 & 1 & 0 & 6 \\
\hline 1 & 1 & 1 & 1 & 0 & 7 \\
\hline 3 & 1 & 2 & 1 & 0 & 8 \\
\hline 1 & 2 & 2 & 2 & 0 & 9 \\
\hline
\end{tabular}

Berdasarkan ouput syntax Tabel 3, dapat dilihat bahwa SPPS mengkombinasikan stimuli menjadi 9 stimuli dengan penggambungan setiap level dan atribut yang sudah ditentukan sebelumnya. Selanjutnya diterjemahkan kode setiap level ke dalam kuesioner penelitian.

Tabel 4. Hasil Kombinasi SPSS

\begin{tabular}{|c|c|c|c|c|}
\hline Card & Warna & Tempat & Media & Garansi \\
\hline 1. & Biru & Bank & SMS & Ada \\
\hline 2. & Biru & Kios & SMS & Tidak ada \\
\hline 3. & Kuning & PLN & SMS & Tidak ada \\
\hline 4. & Kuning & Kios & Telepon & Ada \\
\hline 5. & Kuning & Bank & SMS & Ada \\
\hline 6. & Putih & Kios & SMS & Ada \\
\hline 7. & Putih & PLN & SMS & Ada \\
\hline 8. & Biru & PLN & Telepon & Ada \\
\hline 9. & Putih & Bank & Telepon & Tidak ada \\
\hline
\end{tabular}

Berdasarkan Tabel 4, menunjukan bahwa kombinasi nomor 1 mempunyai atribut warna dengan level biru, atribut tempat pembelian voucher listrik prabayar dengan level bank, atribut media pengaduan pelanggan dengan level telepon dan atribut garansi kerusakan dengan level ada. Begitu selanjutnya dengan kombinasi yang lain. Dari 9 kombinasi tersebut akan dimasukan ke dalam kuesioner untuk dinilai oleh responden, jadi setiap responden harus menilai 9 kombinasi sekaligus.

\subsection{Hasil Kuesioner}

\subsubsection{Profil Responden}

Pada bagian ini akan dijelaskan mengenai profil responden. Profil responden yang digambarkan dalam kuesioner menyangkut usia, jenis kelamin, tingkat pendidikan terakhir, dan jenis pekerjaan. Adapun data usia responden secara keseluruhan dapat dilihat pada Gambar 2. 


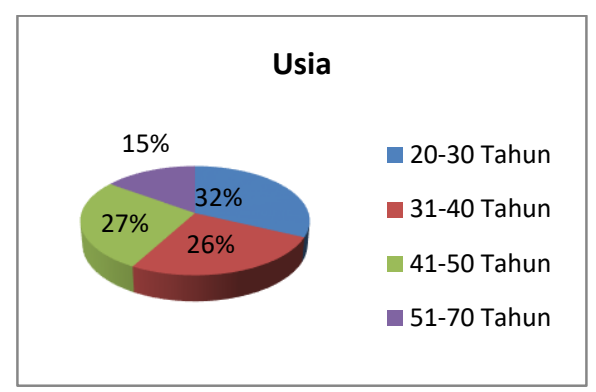

Gambar 2. Usia Responden

Pada penelitian ini berdasarkan usia responden, terdapat 32 responden berusia 20-30 tahun, 27 responden berusia 41-50 tahun, 26 responden berusia 31-40 tahun, dan 15 responden berusia 51-70 tahun.

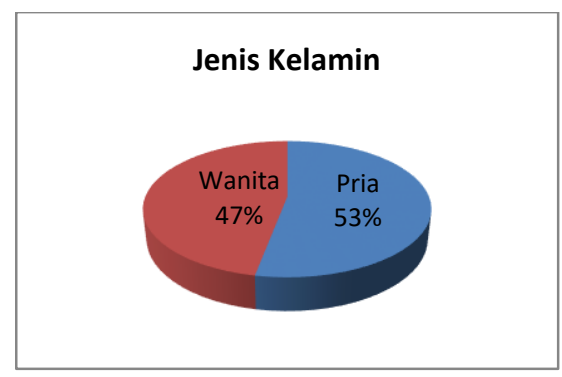

Gambar 3. Jenis Kelamin Responden

Berdasarkan Gambar 3, Dapat dilihat bahwa pada penelitian ini terdapat 53 orang berjenis kelamin laki laki dan 47 orang berjenis kelamin perempuan.

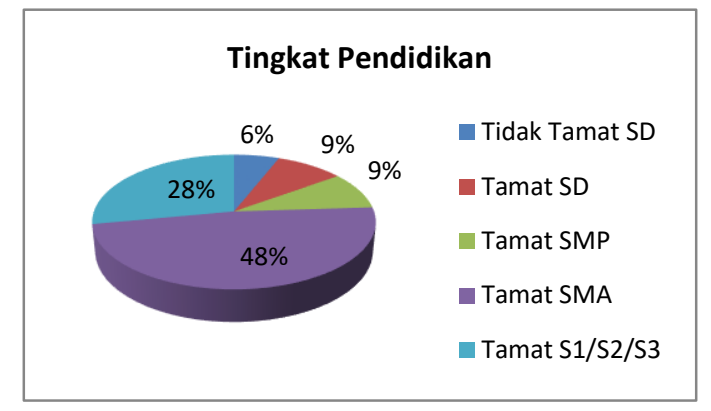

Gambar 4. Tingkat Pendidikann Responden

Berdasarkan Gambar 4 pada tingkat pendidikan, jumlah responden yang tamat SMA sebanyak 48 orang, kemudian disusul responden yang tamat S1/S2/S3 sebanyak 28 orang, tamat SMP sebanyak 9 orang, tamat SD sebanyak 9 orang dan terakhir responden yang tidak tamat SD sebanyak 6 orang.

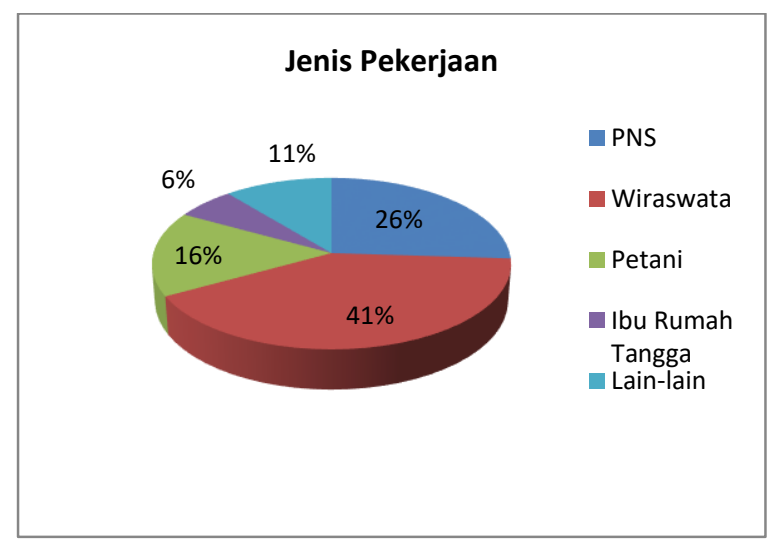

Gambar 5. Diagram Jenis Pekerjaan Responden 
Berdasarkan Gambar 5, menunjukan bahwa dari segi jenis pekerjaan terdapat 48 orang berprofesi sebagai Wiraswasta, kemudian 26 orang berprofesi sebagai PNS, 16 orang berprofesi sebagai petani, 6 orang berprofesi sebagai ibu rumah tangga dan 11 orang berpofesi yang lainya.

\subsection{Uji Validitas Dan Uji Reliabilitas}

\subsubsection{Uji Validitas}

Uji validitas digunakan untuk menunjukan sejauh mana suatu alat ukur (kuesioner) yang digunakan untuk mengukur informasi yang diperlukan. Penelitian ini menggunakan 50 responden untuk mengukur validitas dan reliabilitas. Adapun hasil uji validitas dapat dilihat pada Tabel 6.

Tabel 6. Hasil Ouput SPSS, Uji Validitas

\begin{tabular}{|c|c|c|}
\hline Pertanyaan & Scale Variance If Item Deleted & Keterangan \\
\hline Sikap 1 & 0,287 & Valid \\
Sikap 2 & 0,438 & Valid \\
Sikap 3 & 0,357 & Valid \\
Sikap 4 & 0,292 & Valid \\
Sikap 5 & 0,346 & Valid \\
Sikap 6 & 0,291 & Valid \\
Sikap 7 & 0,350 & Valid \\
Sikap 8 & 0,457 & Valid \\
Sikap 9 & 0,600 & Valid \\
\hline
\end{tabular}

Berdasarkan Tabel 6, dapat dilihat bahwa untuk mengetahui butir soal mana yang gugur dapat dilakukan dengan membandingkan koefisien validitas yang disebut dengan $r$ hitung dengan $r$ tabel pada taraf signifikan 5\%. Berdasakan tabel $r$ diperoleh df $=\mathrm{n}-2=50-2=48$, taraf signifikansi 5\% sebesar 0,2787. Apabila nilai $r$ hitung lebih besar dari 0,2787 maka dapat dinyatakan butir soal dalam kuesioner tersebut dikatakan valid. Sebaliknya apabila nilai $r$ hitung lebih kecil dari 0,2787 maka butir soal dinyatakan gugur. Dari hasil diatas dapat simpulkan bahwa karena $r$ hitung lebih besar dari $r$ tabel, maka semua soal dalam kuesioner dapat dinyatakan valid.

\subsubsection{Uji Reliabilitas}

Hasil uji reliabilitas dapat dilihat pada Tabel 7 berikut.

Tabel 7. Hasil Ouput Uji Reliabilitas dengan SPSS.

\begin{tabular}{|c|c|}
\hline Cronbach's Alpha & N of Items \\
\hline 0.653 & 9 \\
\hline
\end{tabular}

Berdasarkan Tabel 7, dapat disimpulkan bahwa instrument yang dipakai dalam penelitian ini dapat dikatakan reliabel. Berdasarkan hasil uji reliabilitas yang dilakukan diperoleh koefisien alpha Cronbach's sebesar $(0,653)$ Karena koefisien reliabilitasnya lebih besar dari 0,60 maka instrumen untuk mengukur sikap pelanggan terhadap atribut rekening listrik prabayar dapat dikatakan reliabel.

\subsection{Hasil Analisis Konjoin}

\subsubsection{Nilai Utilitas}

Nilai utilitas digunakan untuk mengetahui tingkat kepuasan relatif dari responden. Utilitas tertinggi merupakan nilai yang paling dipilih oleh responden. Pada penelitian ini penyelesaianya tidak dilakukan secara manual karena jumlah responden yang begitu banyak dan proses penyesaian yang begitu lama. Oleh karena itu, penelitian ini tidak dilakukan secara manual namun dengan menggunakan aplikasi SPSS. Adapun hasil penelitian dapat dilihat pada pada Tabel 8 . 
Tabel 8. Nilai Utilitas

\begin{tabular}{|c|c|c|}
\hline \multicolumn{2}{|c|}{} & Utility Estimate \\
\hline \multirow{3}{*}{ WARNA } & Putih & 0,017 \\
\cline { 2 - 3 } & Kuning & $-0,030$ \\
\cline { 2 - 3 } & Biru & 0,013 \\
\hline \multirow{3}{*}{ TEMPAT } & PLN & 0,074 \\
\cline { 2 - 3 } & Bank & $-0,195$ \\
\cline { 2 - 3 } & Kios & 0,121 \\
\hline \multirow{2}{*}{ MEDIA } & SMS & $-0,035$ \\
\cline { 2 - 3 } & Telepon & 0,035 \\
\hline \multirow{2}{*}{ GARANSI } & Ada & 0,823 \\
\cline { 2 - 3 } & Tidak Ada & $-0,823$ \\
\hline (Constant) & & 2,886 \\
\hline
\end{tabular}

Berdasarkan dari Tabel 8, dapat dilihat bahwa terdapat dua tanda yaitu tanda positif dan negatif. Maksud dari dua tanda tersebut adalah semakin besar nilai (positif) maka semakin besar pula atribut yang diminati oleh responden, begitu sebaliknya semikin rendah (negatif) menunjukan bahwa atribut tersebut kurang diminati oleh responden. Sehingga dapat ditarik kesimpulan sebagai berikut :

1) Warna, dari ke tiga tampilan warna rekening listrik prabayar yaitu warna putih, kuning dan biru dapat dilihat bahwa responden lebih cinderung menyukai tampilan warna rekening listrik yang berwarna putih $(0,017)$ dibandingkan dengan tampilan listrik prabayar yang berwarna biru $(0,013)$ dan kuning $(-0,030)$.

2) Tempat, adapun tempat pembelian voucher yang paling disenangi responden adalah di kios-kios terdekat dengan nilai $(0,121)$ di bandingkan dengan tempat pembelian voucher listrik prabayar di PLN $(0,074)$ dan responden kurang menyukai pembelian voucher listrik prabayar di Bank $(-0,195)$.

3) Media, adapun media pengaduan pelanggan yang paling disenangi responden adalah media telepon $(0,35)$ di bandingkan dengan media SMS $(-0,35)$.

4) Garansi, berdasarkan Tabel 8, dapat di tarik kesimpulan bahwa responden lebih cinderung menyukai listrik prabayar yang memiliki garansi $(0,823)$ dibandingkan dengan listrik prabayar yang tidak memiliki garansi $(-0,823)$.

\subsubsection{Nilai Kepentingan Relatif}

Nilai kepentingan relatif menunjukan tingkat persentase diantara dari masing-masing atribut. Hasil keseluruhan nilai kepentingan relatif dapat dilihat pada Tabel 9.

Tabel 9. Faktor Kepentingan Relatif
\begin{tabular}{|l|c|}
\hline WARNA & 19,81 \\
TEMPAT & 23,95 \\
MEDIA & 10,34 \\
GERANSI & 45,88 \\
\hline
\end{tabular}

Berdasarkan Tabel 9, dapat ditarik kesimpulan bahwa responden (secara umum) cinderung lebih menyukai rekening listrik prabayar yang memiliki garansi kerusakan $(45,88 \%)$ kemudian yang menjadi prioritas kedua bagi responden (secara umum) adalah tampat pembelian voucher listrik prabayar (23,95\%). Sementara tampilan warna rekening listrik prabayar (19.81\%) menjadi prioritas ketiga dan Media Pengaduan Pelanggan (10,34\%) menjadi prioritas keempat.

\subsection{Ketepatan Prediksi}

Untuk menguji ketepatan prediksi dalam analisis konjoin dilakukan dengan menggunkan korelasi Pearson's $R$ dan Tau Kendal. Pedoman untuk uji signigikansi adalah sebagai berikut :

$H_{0}$ : Tidak ada hubungan yang kuat antara variabel estimasi dengan observasi.

$H_{1}$ : Ada hubungan yang kuat antara variabel estimasi dengan observasi. 
Tabel 10. Ketetapan Prediksi

\begin{tabular}{|l|c|c|}
\hline & Value & Sig. \\
\hline Pearson's R & 0,999 & 0,000 \\
Kendall's tau & 0,889 & 0,000 \\
\hline
\end{tabular}

Berdasarkan Tabel 10, dapat disimpulkan bahwa pada perhitungan pearson's maupun kendall, angka signifikan keduanya dibawah 0,05 maka $H_{0}$ ditolak. Hal ini berarti ada korelasi yang cukup kuat untuk menggambarkan kondisi aktual antara hasil analisis konjoin dengan pendapat responden.

\section{Kesimpulan}

Berdasarkan hasil dan pembahasan, diperoleh kesimpulan sebagai berikut :

1) Hasil penerapan analisis konjoin untuk mengetahui preferensi pelanggan listrik prabayar di Kota Ambon, diketahui bahwa pelanggan lebih menyukai tampilan warna meteran listrik prabayar yang berwarna putih, tempat pembelian voucher listrik di kios-kios terdekat, media pengaduan pelanggan melalui telepon dan memiliki jaminan garansi.

2) Faktor yang paling diperhatikan oleh pelanggan listrik prabayar di Kota Ambon adalah faktor jaminan garansi dari listrik prabayar dengan kepentingan relatif sebesar 45,88\% di bandingkan dengan faktor lainya.

\section{Daftar Pustaka}

[1] P. Kotler, Alih bahasa and M. Benyamin, Manajemen Pemasaran, Klaten: PT Intan Sejati.

[2] M. I. Yusi and N. Widowati, “Analisis Pelayanan Listrik Prabayar di PT. PLN (Persero),” Jurnal Jurusan Administrasi Publik, 2013.

[3] B. Simamora, Analisis Multivariat Pemasaran, Jakarta: PT. Gramedia, 2005.

[4] Arikonto and H. Friska, “Analisis Konsumen Terhadap Atribut Etool Card,” Jurusan Teknik Universitas Indonesia, Jakarta, 2006.

[5] I. Susanti, "Penetuan Atribut Telur Asin Berdasarkan Preferensi Konsumen," Jurusan Teknik Industri Universitas Sebelas Maret, Surakarta, 2011.

[6] J. F. Hair, C. B. William, J. B. Barry, E. A. Rolph and L. T. Ronald, Multivariate Data Analysis, 6th ed., New Jersey: Pearson Prentice Hall, 2006.

[7] H. Usman and N. Sobari, Aplikasi Teknik Multivariate Untuk Riset Pemasaran, Jakarta: PT. Prajagrafindo Persada, 2013.

[8] W. G. Cochran, Teknik Penarikan Sampel, Jakarta: UI Press, 2001.

[9] Sugiyono, Metode Penelitian Bisnis, Bandung: Alfabeta, 1999. 